\title{
Towards Inner-Directedness: Biographical Narratives of Early Adulthood
}

\begin{abstract}
The article is an example of research done with the biographical method within the framework of educational biography. In the text I present the key elements and stages of the applied research procedure (biographical workshops for young adults) and an example of using it in practice (i.e., obtaining qualitative data from written self-narratives, supplementary techniques and the analysis and interpretation carried out by the narrator). The research conclusions highlight the significance of using tasks of this kind in work with young adults. They show the opportunities but also limitations of using the biographical method, which result from the subjects' young age. They describe a number of functions (including auto-therapy) that help them formulate their own judgements, gain autonomy in making decisions, and the sense of control of their own lives.
\end{abstract}

\section{Keywords:}

qualitative research, inner-directedness, educational biography, early adulthood, written (self-)narrative

\section{INTRODUCTION}

Pierre Dominicé (2006) does research involving the use of educational biography of adults in order to develop their personalities. The key assumption of this approach is that when talking about their past, adults make a biographical reflection, which is the basis for their personality formation. Strengthening the sense of inner-directedness through biographical narratives gives people an opportunity to

1 Faculty of Education, University of Białystok, Poland.

E-MAIL: k.czykier@uwb.edu.pl ORCID: https://orcid.org/0000-0002-9310-6415 
develop the ability to control their own development and make good choices and decisions in their lives, including professional, family and other situations. The aim of this study is to present the results of research on the importance of young adults' participation in biographical workshops in strengthening their sense of inner-directedness understood as the awareness of their own development and the ability to direct their lives. Based on the aim of the study and my research assumptions, I make the thesis that when analyzing their own lives, young adults assign meaning to past events and choices, understand their importance, and thus, they learn from their lives and develop the motivation to construct their lives anew. Self-reflection accompanying the narrative leads to self-knowledge, self-awareness, and consequently, to inner-directedness.

The text presents the theoretical background, the design of the research and the description and discussion of the results.

\section{THEORETICAL BACKGROUND}

\section{INNER-DIRECTEDNESS AS A DISPOSITION OF ATTRIBUTING MEANINGS}

Classic interpretations of the discussed category in social sciences most often refer to the American school of sociology and the concept of "inner containment" derived from the theory of social control developed by American criminologist W. Reckless (1961). In that approach, an inner-directed person is able to control their own behavior. Such a person is active, independent of others, and able to make decisions and take the responsibility for them. A similar interpretation (though based on different sources) is present in the concept of "inner-direction" deriving from the diagnosis of the American society by D. Riesman in The Lonely Crowd (first edition: 1950) (Riesman, Glazer, \& Denney, 2001). In this approach, inner-direction is a type of personality that is characteristic of modern societies. This quality is manifested in relying on one's own judgements and autonomous decision-making. An inner-directed person has the sense of control of their own life (Riesman, Glazer, \& Denney, 2001).

In his social learning theory, Julian B. Rotter (1954) points to two kinds of locus of control determining certain human behaviors. The belief in an external source of control makes the person feel dependent on the environment, controlled by other people (family members, the educational system or mass media) as well as on requirements, prohibitions, instructions, punishments, or rewards. The belief in an internal source of control gives the person the sense of subjectivity and allows them to make autonomous decisions using their knowledge, the crite- 
ria of evaluation of different states and standards of behavior (Poznaniak, 1991). Thus, inner-directedness and outer-directedness are personality traits stressing the main sources of the person's behaviors. Inner-directed people make conscious choices and decide about their lifestyles. They have their own system of values and standards, including the principles and norms of behavior acquired in the process of socialization. They are active, because they are convinced that they have a considerable influence on their lives. Outer-directed people do not have their own, strongly grounded values; they adopt the way of behavior of people surrounding them and they are less immune to social pressure, propaganda and manipulations.

Humans do not only respond to the reality but they also actively construct it and predict the effects of their activities. The most important is the way humans perceive the reality and the meanings they attribute to it (Rotter, 1954). My view, resulting from many years of didactic and educational work with young adults, is that people's "inner-directedness", understood as the awareness of their own development and the ability to control their own lives, should be reinforced, especially that in adulthood (beginning with its early stages), development involves internal integration, extension and deepening of insight and improvement of the axiological orientation (Allport, 1961).

For the needs of the analyses, in this article "inner-directedness" is interpreted as human self-reflection allowing them to make conscious efforts contributing to the development of their personality and creating their own way of life. I assume that as young adults analyze their lives, they attribute meanings to past events and choices, understand their importance, and thus, learn from their own lives and develop the motivation to construct them anew. Self-reflection (self-education) accompanying narratives (i.e., creating meanings) leads to self-knowledge, selfawareness, and inner-directedness (Jankowski, 1999; Czerniawska, 2000, 2004; Horsdal, 2004; Dubas, 2005).

\section{BIOGRAPHICAL POTENTIALS OF EARLY ADULTHOOD}

From the point of view of human developmental patterns and the biographical approach, the best moment for reflection on one's life experiences is middle or late adulthood (old age) (Levinson et al., 1978). Why, then, do I focus on young adults in this study? First of all, it is connected with the need to strengthen young people's (self-)reflection leading to the "inner-directedness" described in the previous paragraph. It is associated with building self-esteem, which in adolescence results from the individual's definition of their role and performing tasks approved of in their community and is the key element of personality development. 
According to Levinson's (1978) classification, a young adult is in the second main stage: early adulthood (from age 17-22 to 40-45). This stage is the time of the highest physical and intellectual fitness, life autonomy and creative expansion leading to self-actualization on various planes. It is a period when many tasks, responsibilities and ambitions are accumulated and sometimes hard to combine. According to Levinson, in the "transition period" (age 17-33), people make their first important decisions and establish their position in the society. The main task for the individual is to form the most suitable life structure, ${ }^{2}$ which will ensure them the ability to function stably in the environment. The means to achieve this are steps such as learning about the world of adults, self-identification as an adult, developing interests, adopting the 'adult' system of values and making weighty decisions concerning employment, marriage and family. This requires a lot of effort and trials, so this stage is very difficult. According to Erik H. Erikson (2002), typically, a person in this developmental phase simply cannot integrate fragments making potential components of their identity into one coherent and integral system easily and without conflict (Erikson, 2002). This system reflects anything the person is and wants to be for themselves and for the environment as well as the reciprocal approval by the environment, which gives them the upbuilding sense of existential fulfilment and mental comfort (Nalaskowski, 1998; Witkowski, 2000; Wasilewska, 2005). In my opinion, the above-mentioned comfort can be achieved through conscious selfreflection aiming at cognitive development of self-concept including the elements of self-knowledge. This is possible using the biographical method, which provides insight into one's own past and the way of self-cognition. From this perspective, it is justified to look for biographical potentials of early adulthood.

As a result of a sequence of developmental patterns, the person achieves adulthood. According to Olga Czerniawska (2000), adulthood is a state of personality, the result of educational and self-educational measures manifested in one's behavior, the approach to social norms and roles established in the society for its members who achieve a certain age. It develops under the influence of intended and unintended effects of the socio-cultural environment in which the person lives and the values upheld in it (Dubas, 2004). Adulthood includes two kinds of meanings (also present in the biographical approach): the objective meaning, which refers to the social norm and the phase of human life determined by the chronological framework, and the subjective meaning, reflected in the person's experiences (Czerniawska, 2000).

2 The life structure, as perceived by D. Levinson (1978), is the present pattern of one's own activity in combination with external factors. It depends on two groups of factors, i.e., external and internal ones - factors independent of the person, resulting from the external situation, and factors being the effect of the person's conscious activity. 
It must be mentioned here that the biographical method, analyzing the attribution of subjective meanings by individuals taking part in biography writing, results in a broader, objective image of phenomena or the generation involved in them.

\section{THE BIOGRAPHICAL METHOD: A NEW VERSION OF LIFE}

Biographical methods or biographical studies are connected with the category of biographical approach (Dubas, 1996). Biographicity is present in andragogical reflection concentrated on the study of biography (Dubas, 2005, p. 11). Biographicity is the key term in the original concept by P. Alheit (1990), in which the Author interprets it as a personal competence which refers to individual human experience, mostly connected with the process of learning related to biography (Alheit, 1990, p. 6). As stated by Ewa Skibińska (2006), biographicity is connected with "the individual constantly transforming their life that occurs in specific conditions, with the persistent belief that he or she is able to plan and change that context” (Skibińska, 2006, p. 17). Agnieszka Bron (2007) expresses a similar view. Referring to the concept by P. Alheit, she defines biographicity as the construction and reconstruction of an adult's life, as the person's ability to design their life anew again and again (Bron, 2007). Thus, the idea of biographicity directly refers to the pedagogical dimension of biography, which should be understood as specific biographical resources, potential, or capital (Lalak, 2010, pp. 110-111). Interest in human biography is visible in the so-called emancipatory educational approach.

In education for adults, biographicity is closely related to the category of lifelong learning (cf. Czerniawska, 2000, 2011; Dubas, 1998, 2000, 2009, 2015). Reflections present in this trend show adults as biographical creatures, and their learning and education processes as relevant to their ontological nature. Biographical studies are designed to learn the person's life situation against the background of their direct environment and the ways of making use of the values of broader communities (Czerniawska, 2000). For the process of education, it is necessary to identify the individual's subjective environment - what they live with and what they create around them.

The main ideas of educational biography concentrate on enabling adult students to analyze their own experiences connected with learning and education, to reflect on situational influences, life events and the details of their educational biographies (cf. Demetrio, 2000).

\section{STUDY DESIGN}

The presented study follows the trend of qualitative research in the interpretative paradigm, "studying the subjectively experienced social reality constructed by 
people” (Piorunek, 2016, p. 8). The applied method was the biographical research method, which has been popular again in social sciences for the last few decades, i.a., in sociology, history, psychology, pedagogy and other fields.

The subject of study was the sense of inner-directedness in young adults. The aim of the study was to try to determine the importance of young adults' participation in biographical workshops in reinforcing their sense of inner-directedness.

\section{PARTICIPANTS}

The study sample was purposively selected. The participants were students of pedagogy at the Faculty of Education, University of Białystok. In my opinion resulting from many years of didactic and educational work with young adults (students of pedagogy), it is necessary to reinforce people's “inner-directedness" understood as the awareness of their own development and the ability to control their own lives. This particularly refers to pedagogy graduates, as they are going to work with other people in the future.

In November and December 2019, as part of Andragogy classes, two sessions of biographical workshops (1.5 hour each) were conducted in 7 groups (between 17 and 25 people). 155 students (143 women and 12 men aged 20-24) took part in the study. In the theoretical part of the workshops, the participants were educated about the biographical method, its history, ways of application, functions, and the category of inner-directedness. In the practical part, the participants received examples and precise instructions concerning the techniques and instruments used in the study.

Taking into consideration the specificity and difficulty of using the biographical method in working with young adults (cf. Karpiak, 2000; Rossiter, 2002), the material for research was obtained in the form of written expressions of workshop participants. They included a biographical text, a choice map, a lifeline (a table plus a diagram) and the analysis and interpretation carried out by the participant on the basis of the received instructions. ${ }^{3}$ After the workshop, each participant had 3-4 weeks to personally prepare all the above-mentioned components. As the author of the study, I was available for consultation all the time.

Workshop participants were free to decide whether they wanted to do the tasks on the basis of their own lives. All in all, 104 participants did so (93 women and 11 men). From this group I selected the cases that met all the criteria I had adopted, i.e., included a biographical text (generated on the basis of responses to all the questions included in the interview questionnaire), a choice map, a lifeline

3 Particular components are discussed in greater detail in the section 'Data collection and analysis'. 
(table and diagram) as well as an analysis and interpretation. This way, I identified 32 cases (27 women and 5 men) which in my opinion provided research material with high cognitive quality. I present this material in the article.

\section{DATA COLLECTION AND ANALYSIS}

The procedure of collecting biographical material involved several stages. The starting point was the preparation of an interview questionnaire. The questions I prepared were divided into three theme blocks: 1) Childhood: earliest memories until the school time, 2) School time and adolescence, 3) Beliefs concerning life values and goals. The data obtained through written self-narratives (the biographical text) was subject to analysis and interpretation. Supplementary techniques such as choice map (Lewchanin \& Zubrod, 2001) and lifeline (Birren et al., 1996) in modified versions were also used in collecting data.

The “choice map" developed by Shari Lewchanin and Louise A. Zubrod (Figure 1) is an instrument that facilitates the review of one's life. This simple technique is based on graphic representation of a map of paths describing the respondent's important life choices.

\section{Figure 1. Choice Map}

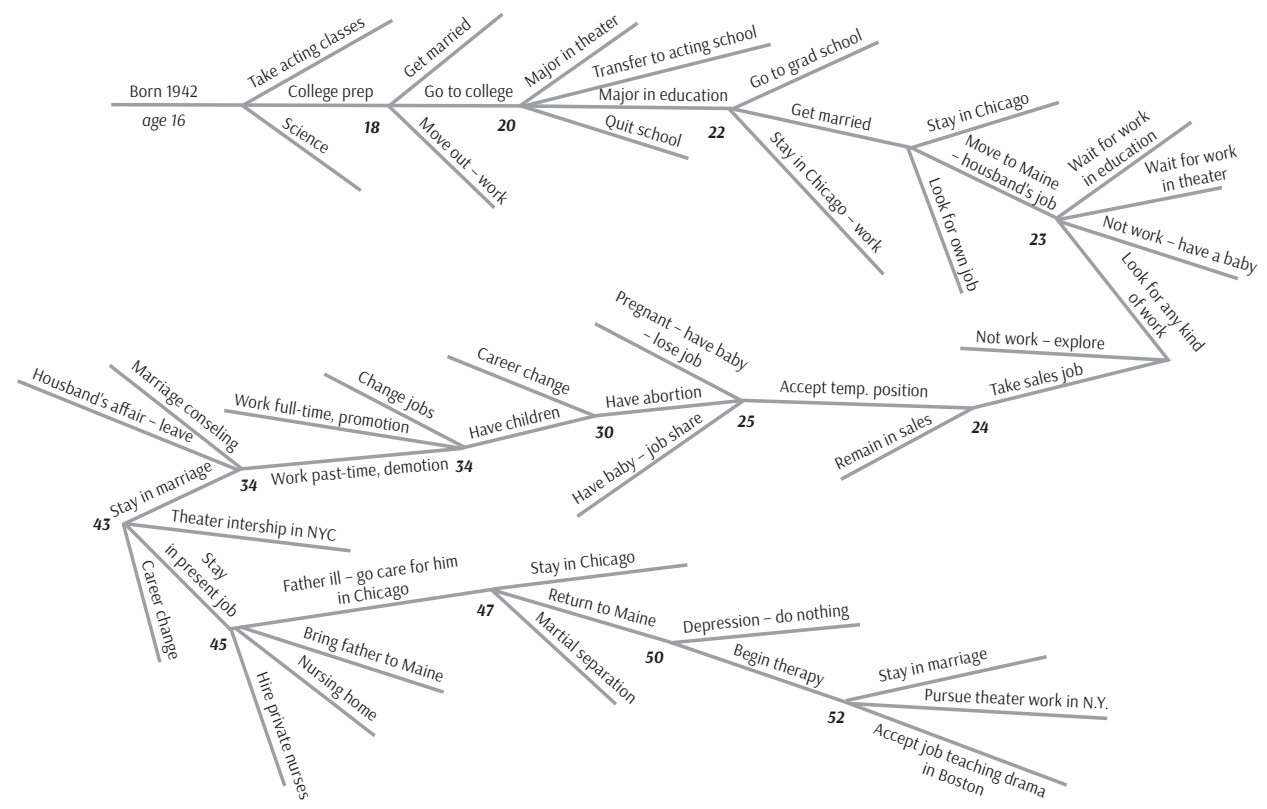

Source: Lewchanin \& Zubrod, 2001. 
The respondents identify the most important breakthrough moments in their lives from birth until the present time, assigning them the level of significance. Then, they provide their age at the moment of making each decision and specify alternative choices (the paths that they did not choose). The important modification of the technique is that the respondents describe the events that accompanied the choices as well as their consequences. The respondents are encouraged to identify as many options as possible, even the alternatives they were not aware of at the moment of making the choices. It is important to identify the choices that were made (both dependent on and independent of the person) and to realize the importance of the ones that were not made for different reasons. There is not just one way of doing this task. The respondents may begin drawing the map with the age they feel they made the first significant choice. When making the choice map, they review their lives, thus preparing for the next chapters of their lives. As a result, this process will support their individuality and the skill of making choices. This is also evidenced by the research results discussed in this text.

Another stage of the research involved making a "lifeline". It is a modified version (corresponding to the previously described technique) of the proposal by James Birren et al. (1996). In the research it was presented in two parts: a table and a diagram. In the first part, on the basis of information included in the choice map, the respondent's task was to enter data into a table presenting the following elements: 1) age (the age at which the person made the choice), 2) the branch-off point ${ }^{4}$ (description of the breakthrough moment when the choice was made; the moment may produce several alternatives or just one), 3) events (which took place between particular branch-off points), 4) affect (specific emotional evaluation of each described event accompanying the situation of choice; emotional evaluation is done from two perspectives: "past", when the event occurred directly in the respondent's life, and "present”, when the same event is evaluated from the perspective of the present day5).

The table is supplemented with a diagram, i.e., graphical representation of the attributed affects (Figure 2).

The $\mathrm{x}$ axis of the diagram is described as the affect, and the y axis represents age. The diagram actually includes two lifelines: the affect in the past and the

4 Term corresponding to the alternative name of the choice map, i.e., "the tree of life".

5 Emotion sign attributed to each event: “+” (positive), “o” (neutral), or “-” (negative); the "+” or "-" values do not mean that an event was very important or unimportant - all events are important because they were mentioned by the respondent; the “+”, “o”, or "-” signs are a kind of illustration of emotions attributed to particular events in the past and in the present - they may be the same or completely different. 
affect in the present. The diagram coordinates were identified by means of determining the mean emotion sign attributed to each event between one branch-off point and another. The diagram presents the image of the respondent's life (from a specific perspective) and has the character of graphic illustration, specific complementation of the information included in the biographical text and presented on the choice map.

\section{Figure 2. Example of a Lifeline Diagram}

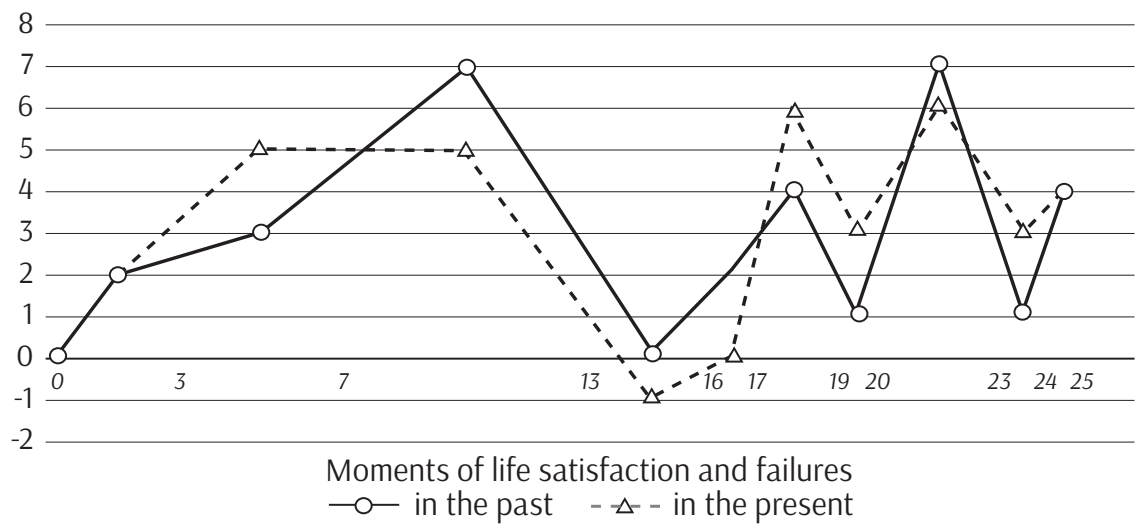

Source: author's own study.

The diagram provides information connected with the moments of life satisfaction and failures (evaluated as such in the past and in the present), but the image becomes clear and full only in comparison with the data obtained with the techniques described before.

The last element of the applied procedure of collecting biographical material was the analysis and interpretation carried out by the narrator. It includes all the data produced during the study: from the biographical text, from the choice map, from the table, and from the diagram.

We must remember, however, that people have different levels of interpretation skills and different experience in interpreting facts. Therefore, the respondents were given substantial freedom of interpretation, but were guided with the researcher's choice of areas. These areas were: 1) identification and description of breakthrough moments, 2) determination and description of choice alternatives, 3) determination of internal and external determinants of choices, 4) determination of the cause and effect relationships between breakthrough moments, events, choices (their character) and the present situation of the person. 


\section{RESULTS}

Due to limitations of the text, I omit graphical presentations of narrative threads (illustrated in the technique of choice map and in the lifeline chart). Both interrelated techniques provide important information to complement the entire narrative. In fact, this is too extensive material and constitutes data for separate publication. For the sake of providing a complete picture of the data collection procedure and its interpretation, it is important to mention some of the repetitive tendencies seen through the use of these techniques. There are two trends:

- idealization of childhood,

- seeking development potential in past crises.

Illustrated on the choice map, sequences of consecutive breakthrough moments, choices (along with their alternatives) and events were most often related to the educational path. I describe them in the further part of the text.

Interesting information is provided by the lifeline technique (completed with a graph). Let me remind you that the task of the respondent was to assign affect to each previously described event accompanying the situation of choice. This evaluation is done from two perspectives: "past”, when the event occurred directly in the respondent's life, and "present”, when the same event is evaluated from the perspective of the present day.

The analysis shows that events assessed from the perspective of the present were more often evaluated positively than before. This tendency is significant especially for childhood. A proposal for the idealisation of the childhood period can be formulated. This also applies to those cases when childhood was in fact saturated with unpleasant events. This trend is evident in the constructed lifeline technique graph.

Participation in biographical workshops resulted in reflection on past events and finding development potentials in them. It is natural that it has a very individual dimension, conditioned by many environmental factors (family influences, peer group, place of residence, etc.). This is also confirmed by the respondents' statements (exemplifications in the paragraph 'Towards inner-directedness'). It follows that, for many, the current biographical narrative makes it possible to interpret past crisis situations as a learning situations that enrich the experience. Giving a new sense (usually positive) to situations experienced in the past can be regarded as moving towards inner-directedness. For many, re-confronting situations of the past (often repressed) was a kind of self-therapy. 
In order to present the collected material, I used analytical abstraction of all the cases in which "the researcher tries to identify in the text the categories common for other narratives and the ones that are specific for the currently studied narrative and consider them as contrasting cases” (Kaźmierska, 1997, p. 43). I used the strategy of contrast comparison.

Since some of the respondents' narratives were very personal, I will limit the presentation of results to general tendencies.

\section{BREAKTHROUGH MOMENTS}

The breakthrough moments identified by the respondents were mostly related to crossing (beginning) successive educational thresholds: elementary school, junior high school, high school, and university. Despite the respondents' young age, however, these were not the only breakthrough moments. For some respondents, the moments that caused changes in their lives were also connected with other situations: both positive (e.g., the birth of brothers or sisters, serious intimate relationships, starting the first job), and negative (e.g., father's alcohol addiction, parents' divorce, having to move house, an accident, disease or death of a family member or friend).

\section{CHOICES AND THEIR ALTERNATIVES}

The choices made by the respondents (and their alternatives) were usually connected with their educational path. The choices the respondents mentioned first especially referred to the choice of high school. For people living in rural areas, this choice was often connected with solving dilemmas such as whether to commute to school or move for the time of school education (to stay in a boarding house, a dormitory or with some relatives). The period of school education was also full of dilemmas related to the respondents' interests and passions.

All of them pointed to the choice of the university major, which is not surprising taking into consideration the specificity of the study group. The respondents also mentioned dilemmas typical of early adulthood, related to taking on a job, moving in with a boyfriend or girlfriend, relations with a group of friends, building one's personal life, as well as religious and existential dilemmas.

\section{INTERNAL AND EXTERNAL DETERMINANTS OF CHOICES}

The participating students were able to determine the character of the choices they had made as dependent on them or independent of them. What was common for all the analyzed cases was that most choices regarding the stage of compulsory education did not depend on them. The decisions were made under the influence of 
external factors (mostly the suggestions or even pressure of parents). The respondents' first autonomous choices (although still made with consideration of the opinions of family members) were connected with choosing the high school.

They identified choices made after coming of age, connected, i.a., with university education, leaving home or moving in with their boyfriend or girlfriend as fully dependent on them. In the course of analysis, I identified motives connected with the need to become independent, to grow up, sometimes even to act against the will and pressure of the community (rebellion). Another motivation for making autonomous decisions is the specific balance of profits and losses, involving family members, friends, the place of residence and the financial situation. Autonomous choices were often made with evident support and approval of the closest ones.

\section{CAUSE AND EFFECT RELATIONSHIPS}

The analyses show that the respondents were able to grasp cause and effect relationships between breakthrough moments, choices (their character), and the present personal situation. In comparison with previously presented areas, in this case it was hard to identify common, recurrent elements of the narratives.

Some respondents pointed out that all the past situations and events had their causes and have resulted in their present personal situation. Others managed to precisely identify the relationship between their present situation and past experiences. In doing so, they pointed to the logical and natural character of their entire life course, which for them was always obvious and performed with the support and love of their families. Some respondents only perceived that relationship now, not being aware before that apparently unimportant events and decisions from the past had an influence on what kind of people they are now. There were also some who did grasp the cause and effect relationship but regarded it as incidental, i.e., thought it was not the effect of consciously made decisions. Some respondents mentioned the existence of a cause and effect relationship between their present situation and the events which took place in their early childhood. They do not personally remember those events (they learnt of them from family members' accounts), but they believe those events caused a series of events whose consequences they are still experiencing currently (e.g., parents' divorce or father's alcohol addiction $v$ s frequent changes of place of residence, the family's poor financial condition or personality problems).

\section{TOWARDS INNER-DIRECTEDNESS}

Using the strategy of contrast comparison, I identified the recurrent, common elements of respondents' narratives concerning the discovery or strengthening of the 
sense of inner-directedness. To illustrate this, I provide some examples of the respondents' expressions:

"Thanks to writing the biography, I was able to organize the events and learn what has made me the person I am now. It proved to be very revealing and it allowed me to appreciate all the events and choices from my past" (M, age 23).

"Before writing the biography, I tended to assess my life negatively. I thought I could have chosen better and been wiser. Now I see how much I underestimated my life and choices, how critically I assessed myself and my ability to make choices" (F, age 22).

"By writing the biography, I realized how many important decisions I had made by myself and I understood that life means constantly making decisions which may affect our future" (F, age 21).

"I have never reflected so deeply on my life before. I had some time to analyze how my life had developed, but also to think what it might have been if had made other choices. I have realized what alternatives I had and why I did not choose them" (F, age 20).

"I saw what had motivated me in the past and what I would do in such situations nowadays. I could see the evolution of "myself". [...] The biography showed me my life, event after event, thanks to which I could see a coherent series of events. I think nothing in our life happens without a cause, and my choices were always motivated by something" (F, age 21).

"Before, I was not aware of how much apparently unimportant events or situations may influence us. As I was writing, it came to me that nothing happens without a cause" (F, age 20$)$.

"I think everybody should analyze and write their own biography like I did. Not after retirement, but regularly. I think this can give people a lot of food for thought and teach them something new about themselves” (F, age 20).

The above example expressions show that for the respondents, participation in biographical workshops was the opportunity to reflect on the course of their lives, and thus, gave them a broader perspective in understanding adulthood. Therefore, writing the biography contributes to gaining or strengthening the sense of innerdirectedness.

\section{DISCUSSION}

The obtained results in some areas can be interpreted as consistent with the findings by Irene Karpiak (2000), who focused on the use of autobiographical writing in working with students (young adults) in her research work. In her opinion, such writing leads to learning and growth, because it allows adult students to 'enliven' 
the sense of order, to highlight the moments of decisions, to 'close' the painful events and to gain insight into their own development.

On the basis of the conducted research, it can be concluded that pursuing innerdirectedness requires a diagnosis of the actual state the writer of the biography is in. By analyzing their own choices, the respondents are also forced to identify the choices they did not make (the alternatives). In this regard, it is important to have the ability to differentiate between the options that are no longer accessible and ones that still exist in some forms (substitutes). The respondents' determination of whether particular choices depended on them or not is related to the determination of so-called invisible environment (the "memory of heart”) (Czerniawska, 2000), which does not only refer to material factors and geographical locations but also to other people (family members, friends, teachers). On the one hand, the "memory of heart" is an important element of summarizing one's life so far, and on the other hand, of constructing its current meaning. Conscious choices allow adults to gain the ability to grow in the time of transformations. What is more, active choices and responsibility for them are important for development at a higher level of consciousness and moral thinking. The analysis of cases shows that independent choices were more often made as the respondents were near the coming of age.

All the participants also identified cause and effect relationships. However, in the course of analysis, it was hard to find recurrent elements of narratives common for many individual cases. Instead, there were some ambiguities and differences in interpreting similar categories. It proves that in this regard there are many individual, family and environmental variables which determine differences in perceiving the causes and effects. Perhaps this area should be explored more deeply in the future. In several cases I analyzed, the phenomenon of catharsis occurred as the person was writing. However, due to very personal (sometimes even tragic) narratives, I did not present this issue in greater detail, although it is very important. The respondents also stressed the importance of critical situations as "situations that support inner-directedness” (M, age 21).

\section{CONCLUSION}

The cognitive value of writing about one's own experiences is available both for the writer and for the researcher, but its depth can be best perceived by the person who analyzes their life, i.e., the author of the biography. As shown by the research results presented in the text, preparing a biography allows young adults to reflect on and discuss their own experiences, which as a result reveals the elements of their critical 
thinking, active search for meanings, interpretation and sensitivity to situational impacts. This provides the opportunity to find out what they know and how they can gain individual meanings and senses from the analysis of their own experiences. Self-reflection accompanying the narrative leads to self-knowledge, self-awareness, and contributes to the acquisition and strengthening of inner-directedness.

\section{References}

Alheit, P. (1990). Biographizität als Projekt: der "biographische Ansatz" in der Erwachsenenbildung. Bremen: Universitat Bremen.

Allport, G.W. (1961). Pattern and Growth in Personality. New York: Holt, Reinhart \& Winston.

Birren, J.E., Kenyon, G., Ruth, J.E., Shroots, J.J.F., \& Svensson, J. (1996). Aging and Biography: Explorations in Adult Development. New York: Springer.

Bron, A. (2007). Learning, Language and Transition. In: L. West, P. Alheit, A.S. Anderson, \& B. Merrill (Eds.), Using Biographical and Life History Approaches in the Study of Adult and Lifelong Learning: European Perspectives (pp. 205-220). Frankfurt: Peter Lang.

Czerniawska, O. (2000). Drogi i bezdroża andragogiki i gerontologii. Łódź: WSHE.

Czerniawska, O. (2004). Dylematy andragogiki. Między nauczaniem, uczeniem się a autoedukacją. In: J. Kostkiewicz (Ed.), Aksjologia edukacji dorosłych (pp. 109-118). Lublin: Wydawnictwo KUL.

Czerniawska, O. (2011). Nowe drogi w andragogice i gerontologii. Łódź: Wydawnictwo Akademii Humanistyczno-Ekonomicznej w Łodzi.

Demetrio, D. (2000). Autobiografia. Terapeutyczny wymiar pisania o sobie. Kraków: Oficyna Wydawnicza Impuls.

Dominicé, P. (2006). Uczyć się z życia. Biografia edukacyjna w edukacji dorosłych. Łódź: Wydawnictwo Wyższej Szkoły Humanistyczno-Ekonomicznej w Łodzi.

Dubas, E. (1996). [Review of the book: Biographizität als Projekt: der "biographische Ansatz" in der Erwachsenenbildung, Universitat Bremen, Bremen 1990 by Peter Alheit]. Edukacja Dorosłych, 1(10), pp. 161-170.

Dubas, E. (1998). Biograficzność w oświacie dorosłych - wybrane stanowiska. Edukacja Dorosłych, 3 (20), pp. 33-48.

Dubas, E. (2000). Biograficzność w oświacie dorosłych w ujęciu Olgi Czerniawskiej. In: B. Juraś-Krawczyk, \& B. Śliwerski (Eds.), Pedagogiczne drogowskazy (pp. 162-170). Kraków: Oficyna Wydawnicza Impuls.

Dubas, E. (2004). Podstawowa kategoria andragogiczna „dorosłość” i jej aksjologiczny kontekst. In: J. Kostkiewicz (Eds.), Aksjologia edukacji dorosłych (pp. 199-213). Lublin: Wydawnictwo KUL.

Dubas, E. (2005). Dorosłość w edukacyjnym paradygmacie, czyli dorosłość jako edukacyjny okres życia człowieka. In: M. Podgórny (Ed.), Człowiek na edukacyjnej fali. Współczesne konteksty edukacji dorosłych (pp. 25-38). Kraków: Oficyna Wydawnicza Impuls.

Dubas, E. (2009). Refleksja autobiograficzna jako aktywność edukacyjna w kontekście całożyciowego uczenia się. In: A. Fabiś, \& S. Kędziora (Eds.), Aktywność społeczna, kulturalna i oświatowa dorosłych (pp. 41-53). Mysłowice-Zakopane: Górnośląska Wyższa Szkoła Pedagogiczna w Mysłowicach. 
Dubas, E. (2015). Biograficzność w kontekście całożyciowego uczenia się. In: E. Dubas, \& J. Stelmaszczyk (Eds.), Biografia i badanie biografii. Vol. 4: Biografie i uczenie się (pp. 11-30). Łódź: Wydawnictwo Uniwersytetu Łódzkiego.

Erikson, E.H. (2002). Dopełniony cykl życia. Trans. A. Gomola. Poznań: Rebis.

Horsdal, M. (2004). Ciało, umysł i opowieści - o ontologicznych i epistemologicznych perspektywach narracji na temat doświadczeń osobistych. Teraźniejszość - Człowiek - Edukacja, 2, pp. 9-28.

Jankowski, D. (1999). Autoedukacja wyzwaniem współczesności. Toruń: Wydawnictwo Adam Marszałek.

Karpiak, I. (2000). Writing Our Life: Adult Learning and Teaching through Autobiography. Canadian Journal of University Continuing Education, 26(1), pp. 31-50. DOI: 10.21225/ D5MP43.

Kaźmierska, K. (1997). Wywiad narracyjny - technika i pojęcia analityczne. In: M. Czyżewski, A. Piotrowski, \& A. Rokuszewska-Pawełek (Eds.), Biografia a tożsamość narodowa (pp. 35-44). Łódź: Uniwersytet Łódzki.

Lalak, D. (2010). Życie jako biografia. Podejście biograficzne w perspektywie pedagogicznej. Warszawa: Wydawnictwo Akademickie Żak.

Levinson, D.J., Darrow, C.N., Klein, E.B., Levinson, M.H., \& McKee, B. (1978). The Seasons of a Man's Life. New York: Ballantine Books.

Lewchanin, S., \& Zubrod, L.A. (2001). Choices in Life: A Clinical Tool for Facilitating Midlife Review. Journal of Adult Development, 8(3), pp. 193-196. DOI: 10.1023/ A:1009598425503.

Nalaskowski, A. (1998). Społeczne uwarunkowania twórczego rozwoju jednostki. Warszawa: Wydawnictwa Szkolne i Pedagogiczne.

Piorunek, M. (2016). Liczby i słowa w badaniach humanistycznych i społecznych. (Nie)dychotomiczność paradygmatów badawczych. In: M. Piorunek (Eds.), Badania biograficzne i narracyjne w perspektywie interdyscyplinarnej. Aplikacje - Egzemplifikacje - Dylematy metodologiczne (pp. 7-16). Poznań: Wydawnictwo Naukowe UAM.

Poznaniak, W. (1991). Teorie uczenia się społecznego jako model normalnego i zaburzonego funkcjonowania jednostki oraz grupy. In: H. Sęk (Ed.), Społeczna psychologia kliniczna (pp. 70-98). Warszawa: PWN.

Reckless, W.C. (1961). A New Theory of Delinquency and Crime. Federal Probation, 25, pp. 42-46.

Riesman, D., Glazer, N., \& Denney, R. (2001). The Lonely Crowd: A Study of the Changing American Character. New Haven, CT: Yale University Press.

Rossiter, M. (2002). Narrative and Stories in Adult Teaching and Learning. ERIC Digest. Retrieved from: https://files.eric.ed.gov/fulltext/ED473147.pdf.

Rotter, J.B. (1954). Social Learning and Clinical Psychology. NY: Prentice-Hall.

Skibińska, E.M. (2006). Mikroświaty kobiet. Relacje autobiograficzne. Warszawa-Radom: UW, Wydawnictwo Instytutu Technologii Eksploatacji.

Wasilewska, K. (2005). Psychospołeczny rozwój człowieka dorosłego w świetle koncepcji Erika Eriksona. Edukacja Dorosłych, 2-3, pp. 59-68.

Witkowski, L. (2000). Rozwój i tożsamość w cyklu życia. Studium koncepcji Erika H. Eriksona. Toruń: Wydawnictwo Wit-Graf. 